\section{Community Engagement with Wildlife Conservation in Japan: A Case Study of an Endangered Bird, the Okinawa Rail (Hypotaenidia okinawae)}

\section{MADELEINE SBEGHEN}

University of Queensland

\section{ABSTRACT}

As host of the 2010 Nagoya Biodiversity Summit, Japan reaffirmed its efforts to conserve biodiversity for future generations. Rebuilding relationships with nature and strengthening conservation education are key priorities of Japan's biodiversity conservation agenda to improve outcomes for threatened species and local communities. This paper examines community engagement with the critically endangered Okinawa Rail (Hypotaenidia okinawae), an endemic bird of the Yanbaru forests of northern Okinawa, with reference to the conservation context in Japan. Since discovery of the Okinawa Rail in 1981, communities in Yanbaru have developed a strong relationship with this species, recognising it as an important symbol of regional cultural identity and as a unique ecological asset that attracts visitors and underpins community events. This has translated into investment by government and community stakeholders in conservation education facilities and public awareness campaigns for the Okinawa Rail in Yanbaru. To improve the long-term value of facilities to support science-based conservation efforts in this Japanese context, it could be advantageous to increase opportunities for social learning that incorporate both educational and conservation goals, and which encourage stakeholder partnerships. The complex socio-economic and political context in Okinawa, and the significant impact human activities have on the Okinawa Rail population, also highlight the importance of community cooperation in conservation activities and reinforce the value of interdisciplinary approaches that negotiate cross-cultural differences in biodiversity conservation.

\section{KEYWORDS}

conservation outreach; endangered species; Hypotaenidia okinawae; Okinawa; Okinawa Rail; wildlife conservation; Yanbaru; Yanbaru Kuina
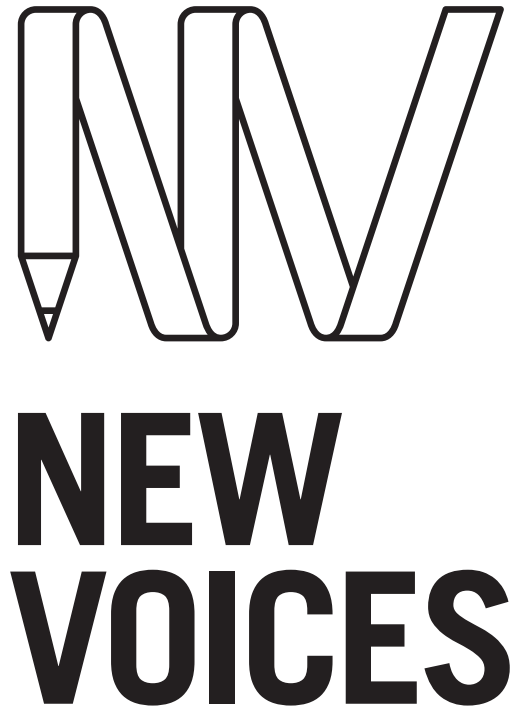

IN JAPANESE STUDIES
JAPANFOUNDATION \&

BRINGING JAPAN TO YOU

To link to this article: http://doi.org/10.21159/nvjs.09.01

\section{ISSN 2205-3166}

New Voices in Japanese Studies is an interdisciplinary, peer-reviewed journal showcasing the work of emerging scholars from Australia and New Zealand with research interests in Japan.

All articles can be downloaded free at newvoices.org.au

(c) The Japan Foundation, Sydney and Madeleine Sbeghen, 2017 


\section{INTRODUCTION}

The Okinawa Rail (Hypotaenidia okinawae) or Yanbaru Kuina (ヤンバルクイナ) as it is known in Japan (hereafter, 'Yanbaru Kuina'), is a threatened bird species endemic to Okinawa, the largest of the subtropical Ryukyu Islands in far southern Japan. Restricted to the relatively small but highly biodiverse Yanbaru (やんばる) forests of northern Okinawa, the Yanbaru Kuina is one of several species in the region with populations threatened by human activity and encroaching development (BirdLife International 2016; Yamashina Institute for Ornithology 2011a). The Yanbaru Kuina is remarkable in that it was only formally described to science in 1981, after which it has been subject to conservation attention and considerable community interest (Yamashina Institute for Ornithology 2011a). As a means to improve outcomes for threatened habitats and species, such as the Yanbaru Kuina, the Japanese government has identified, in line with a growing body of literature, the value of community engagement with biodiversity conservation activities (Government of Japan Ministry of the Environment [MOE] 2012; Government of Japan 2014). Engaging communities in wildlife management and conservation has been recognised as an opportunity to revitalise conditions in rural or remote communities in Japan, where there are significant trends of depopulation and ageing demographics (Sakurai and Jacobson 2011; Government of Japan 2014).

Okinawa provides an interesting context for a conservation case study, as a region with significant biodiversity and endemism, and a complex socio-economic and political history. This includes a long-term interaction with US military forces stationed in Okinawa, and a traditionally disadvantaged economic situation relative to wider Japan, largely based on military services and tourism. The Ryukyu Islands also have a distinct culture unique to the Ryukyuan people, who had independent sovereignty of the region prior to Japanese colonisation in 1879 (International Work Group for Indigenous Affairs [IWGIA] 2016; Kakazu 2011). Conservation efforts for the region's rich but vulnerable biodiversity occur within this complex socio-political environment.

In light of this context and the Yanbaru Kuina's relatively recent discovery, this case study reports on how communities in Yanbaru are interacting or being encouraged to interact with this species, particularly in terms of engagement with conservation. This paper will first describe the context for the biodiversity conservation agenda in Japan and the conservation framework for the Yanbaru Kuina, and then present a snapshot of activities representing community engagement with this species in Okinawa. This is followed by a discussion of how such engagement has impacted communities in Yanbaru, in light of the agenda to revitalise relationships between nature and local communities. Finally, it provides an analysis of community engagement activities relevant to conservation of the Yanbaru Kuina, with reference to successful strategies established in the literature and other conservation contexts in Japan. 
In 2010, Japan took centre stage as host of the Nagoya Biodiversity Summit, the tenth meeting of the Conference of the Parties to the United Nations Convention on Biological Diversity (CBD) (United Nations Environment Programme 2010). The CBD, adopted in 1992, was a major response of the international community to alarming global trends of biodiversity loss (United Nations Environment Programme 2014b). Biodiversity, which encompasses the variation within and between all living organisms on Earth from the genetic level through to species and ecosystems, provides fundamental services which underpin the well-being of human societies (Millennium Ecosystem Assessment 2005). Despite increased targeted action by governments and organisations at international to local levels to address biodiversity loss, biodiversity continues to decline (Rands et al. 2010). It has been suggested that the "primary barrier to meeting the 2010 Biodiversity Target [...] lay in restoring human connections with biodiversity and promoting environmentally friendly behavioural patterns in society" (Jiménez et al. 2014, 830).

The major outcome of the Nagoya Biodiversity Summit was the introduction of the Aichi Biodiversity Targets, which guided the development of National Biodiversity Strategies and Action Plans for 2012-2020 (United Nations Environment Programme 2014c). In accordance with this agenda, Japan published its fifth National Biodiversity Strategy for 2012-2020, which included "mainstreaming of biodiversity into society" and "reviewing and rebuilding the relationships between people and nature in local communities" as two of five basic strategies (Government of Japan MOE 2012; Government of Japan 2014, 35). These strategies incorporated goals to improve opportunities for biodiversity education and experiences, to support the development of communities that better coexist with wildlife, and to promote efforts to conserve wildlife endemic to local areas (Government of Japan MOE 2012, 13-14).

Wildlife management, especially the conservation of threatened species, forms an important part of biodiversity conservation planning. In terms of public engagement, species are a relatable component of the environment to which people develop attachment, and as such they can drive interest in the conservation of a larger at-risk ecosystem. The Japanese archipelago $\left(378,000 \mathrm{~km}^{2}\right)$, comprising four main islands and approximately 6,800 smaller islands, provides habitat for a diverse biota, including approximately 90,000 fauna species (Organisation for Economic Co-operation and Development [OECD] 2010; Government of Japan 2014). National and prefectural governments across Japan publish Red Lists of Threatened Species, which aid in the formation of biodiversity conservation strategies (United Nations Environment Programme 2014a). ${ }^{1}$ The most recent Red List of Japan categorises over 3,500 species as threatened with extinction, including $15 \%$ of bird species, $21 \%$ of mammals, $35 \%$ of reptiles and amphibians, $42 \%$ of brackish and freshwater fish, and 25\% of vascular plant species (Government of Japan 2014).

1 Red Lists are databases that collate taxonomic and distribution information about species from authorities in the field to provide working systematic assessments of conservation status. First developed by the International Union for Conservation of Nature (IUCN), they are a widely accepted tool used to identify threatened species and prioritise conservation actions (IUCN 2016).
Madeleine Sbeghen New Voices in Japanese Studies, Vol. 9, 2017, pp. 1-27 
The statistics in Japan's Red List are indicative of the significant pressures on biodiversity caused by intense periods of development, particularly following World War II, and the demands of Japan's highly urbanised population of 127 million, densely concentrated on the coastal plains (The World Bank 2015; OECD 2010; Japan Bureau of Statistics 2016). Only 7\% of the Japanese population now lives in rural areas, where older generations have become the demographic majority (Government of Japan 2014; The World Bank 2015). This has affected the maintenance of traditional land use and resource management activities, which have often served to support biodiversity (Katoh et al. 2009; Katsue and Yukihiro 2011). Urban residents have relatively fewer opportunities for regular experiences with wildlife and nature (Government of Japan 2014). Globalisation and strong socio-economic drivers in Japan are also eroding the traditional informal protection offered by sacred sites and taboo areas, which has indirectly supported the conservation of some species in Japan (Sasaki et al. 2010).

Although conservation is driven by international agendas and scientific research, conservation activities necessarily occur at local and regional scales, where relationships between communities and natural features are complex and exist within different cultural contexts (Buizer et al. 2016; Elands et al. 2015; Maffi 2010b). In Japan, the most significant tracts of natural forest are found in remote and rural regions, a traditional point of intersection between human settlement and wildlife activity (Government of Japan 2014; Knight 2006). Ageing populations and reduced employment opportunities are growing symptoms of depopulation in these rural areas today (Government of Japan 2014). As the Japanese government has recognised, improving relationships between people and nature through education, wildlife management and conservation activities may provide an opportunity for the revitalisation of these rural communities. The significant impact that human activities have on threatened species means engagement of the community is also crucial to support wildlife conservation efforts (Sakurai and Jacobson 2011; Government of Japan 2014).

A public survey by Japan's National Institute for Environmental Studies found that attitudes towards conservation activities improved when people had greater awareness of the benefits of cultural ecosystem services (Government of Japan 2014, 91-92). The Millennium Ecosystem Assessment established cultural ecosystem services as one facet of a suite of benefits that human societies derive from biodiversity (Millennium Ecosystem Assessment 2005). ${ }^{2}$ Although the ecosystem services model has been criticised for its emphasis on a unidirectional relationship between society and nature, it has aided relevant authorities to evaluate or quantify the intangible benefits of biodiversity (Millennium Ecosystem Assessment 2005; Maffi 2010b). For example, biodiversity contributes to 'cultural' well-being by: reinforcing cultural identity and sense of place; supporting religious and spiritual enrichment; providing a foundation for knowledge systems, education and creative inspiration; and creating opportunities for aesthetic appreciation, tourism and recreation (Daniel et al. 2012; De Groot and Ramakrishnan 2005).

2 Other ecosystem services include: provisioning (of water, food and fibre resources); regulation (of climate, water, disease and waste); and support (for primary production and essential natural cycles) (Millennium 
Meaningful connections with conservation schemes can be fostered through successful negotiation of cultural values concerning nature at the community level (Verschuuren 2012; Hakkenberg 2008; Jepson 2010). That is, gaining community support for conservation may be easier if there are existing cultural associations with or value found in a particular wildlife species, or if there is momentum to cultivate new community relationships with local biodiversity. Barua and Jepson (2010) established that there was a biocultural context for conservation of the Great Bittern (Botaurus stellaris) in the United Kingdom, where this species' representation in the cultural narrative and mythology of an ancient English landscape and identity has strengthened public support and investment in conservation efforts.

In the same vein, the threatened population of Red-crowned Cranes (Grus japonensis) found in Hokkaido has also benefited from strong cultural associations. The crane's long lifespan, graceful pair-bond dancing and distinctive red, white and black colouration has inspired its place as a nationally important symbol of good fortune, marital devotion, longevity and patriotic pride, contributing to its significant representation in art, folklore, domestic objects, textiles and wedding regalia (Von Treuenfels 2006; Britton and Hayashida 1993; Kawauchi and McCarthy 1998; International Crane Foundation 2015). As perhaps the most well-known wildlife conservation story in Japan, this species has received conservation attention from governments, non-governmental organisations (NGOs) and citizens in Hokkaido, from as early as 1924 (Britton and Hayashida 1993). Real progress began in 1952, when local farmers and school children began feeding the small population of cranes over the harsh winter. These efforts laid the foundations for the development of an artificial feeding program, protected areas and several conservation education centres, which have established the crane as a major tourist drawcard and economic driver for eastern Hokkaido (Collar et al. 2001a; Matthiessen 1995; Akan International Crane Center [GRUS] 2015). The Red-crowned Crane was the focus of the first conservation project for the Wild Bird Society of Japan (WBSJ), and continues to be an important species to garner support for this popular NGO (WBSJ 2007, 2014). In a conservation success story for Japan, these combined efforts have seen Hokkaido's Redcrowned Crane population downgraded from Endangered to Vulnerable on Japan's Red List (Government of Japan MOE 2017; BirdLife International 2015). It is clear that the history of cultural associations and community interaction with this species has buttressed conservation efforts.

If conservation is approached from a biocultural perspective, efforts to conserve species should acknowledge the local and wider human context by engaging with communities and, where possible, incorporating cultural values to achieve the most effective outcome for that species, as well as for people in the region (Pungetti et al. 2012; Maffi 2010a). To be most effective, techniques that engage people in conservation programs, such as public awareness campaigns and conservation education, should be tailored to appeal to the communities in which action is required (Lo et al. 2012). These considerations are particularly relevant for threatened species that may not have long-standing cultural value for the regional communities where they 
are found, as is the case for the Yanbaru Kuina. As such, the implementation of conservation activities for the Yanbaru Kuina has coincided with the development of community relationships with this species.

This study therefore sheds light on how communities in a regional area of Japan are cultivating relationships with their local threatened species and participating in conservation initiatives, with consideration for the agenda outlined by the Japanese government to rebuild and revitalise relationships between nature and local communities. ${ }^{3}$ Although an analysis of the effectiveness of education and awareness initiatives in reinforcing conservation outcomes for the Yanbaru Kuina is beyond the scope of this study, some preliminary observations are made regarding effective approaches documented in the literature. While generalisations made in this documentary analysis are limited to the scope of the data collected, this paper provides a snapshot of community engagement with wildlife conservation activities in Japan-a topic not widely disseminated in English amongst scientific and other audiences outside of Japan (Higuchi and Primack 2009). This paper thus joins a growing body of interdisciplinary literature that documents the interaction between cultural values and community relationships with species and landscapes, to investigate the potential application of these interactions to support biodiversity conservation and cultural heritage revitalisation (Maffi 2010c; Buizer et al. 2016).

\section{THE YANBARU KUINA}

\section{Ecology and History}

The Yanbaru Kuina is the only nearly flightless bird found in Japan (Yamashina Institute for Ornithology 2015). Endemic to the island of Okinawa $\left(1,206 \mathrm{~km}^{2}\right)$, Yanbaru Kuina are medium-sized birds with a red bill and legs, olive-brown upperparts, barred-white black underparts and a white line underneath the eye extending down the side of the neck (BirdLife International 2017; see also Figure 1). Similar to other typically flightless species in the Rallidae family, this species has strong legs, short rounded wings and a tail reduced to brushy feathers (Kuroda 1993; Kirchman 2012). This species' small distribution is restricted to the montane Yanbaru forests across the northern region of Okinawa, an area characterised primarily by dense subtropical broadleaf evergreen forests, with a climax vegetation area of $300 \mathrm{~km}^{2}$ (BirdLife International 2017; Collar et al. 2001b; Itō et al. 2000). The Yanbaru Kuina population is considered to be in decline, with a current total population estimate of 720 individuals, including approximately 480 mature individuals (BirdLife International 2017). Consequently, the Yanbaru Kuina is classified as Critically Endangered (Endangered Class IA) in the 2012 Red List of Threatened Species of Japan, and Endangered on the IUCN Red List of Threatened Species (Japanese Red Data Search System 2016b; BirdLife International 2016). 


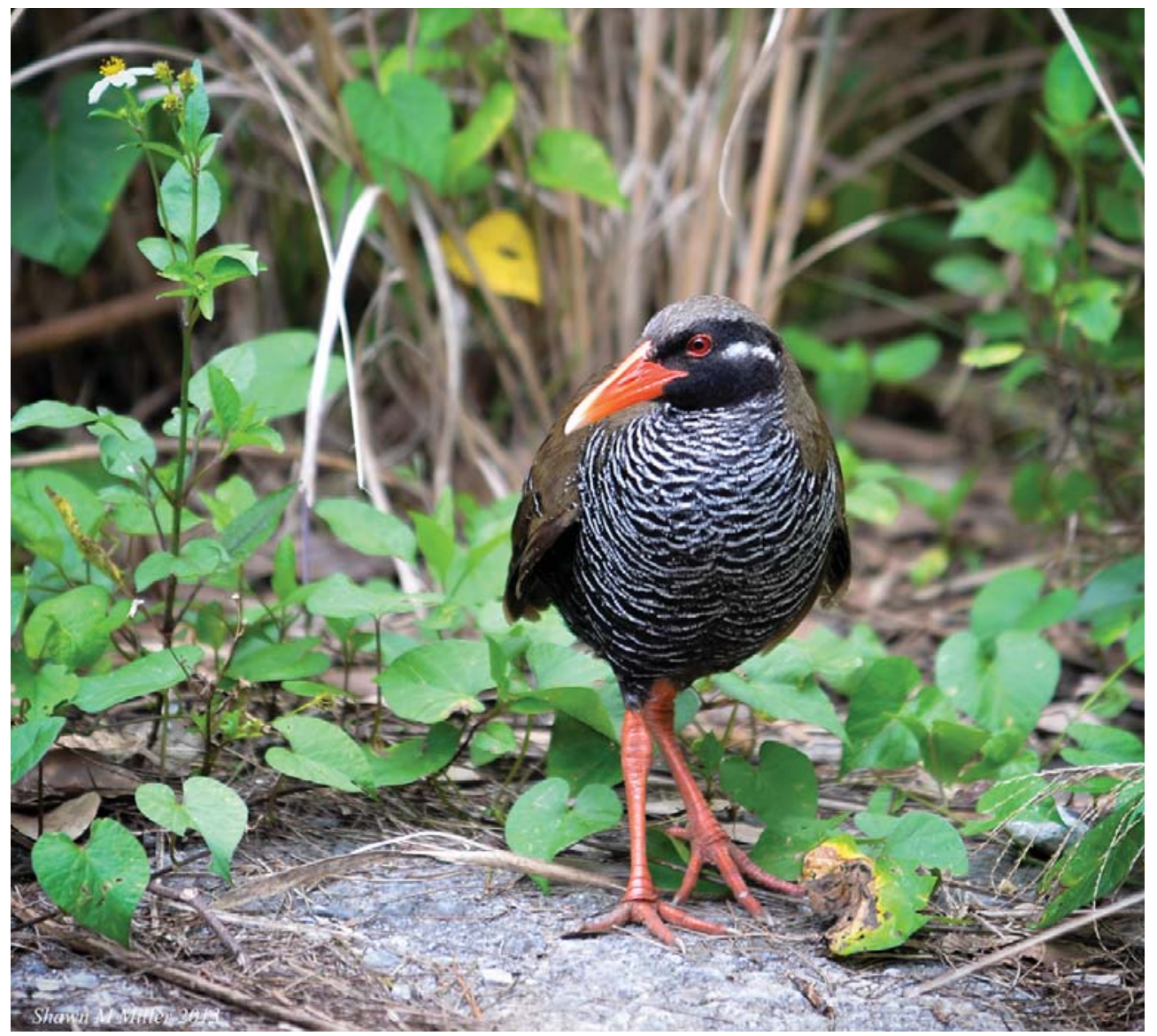

Figure 1: The Yanbaru Kuina (Hypotaenidia okinawae).

(c) Shawn M. Miller 2013. Reproduced with permission.

For a small region, the Yanbaru forests possess significant biodiversity and endemism, being home to $8 \%$ of mammal species, $25 \%$ of reptile species and $25 \%$ of vascular plants found across Japan (Itō et al. 2000). Yanbaru also has a high incidence of threatened species, including four critically endangered mammal and bird species (Itō et al. 2000; Japanese Red Data Search System 2016a). Island species that have restricted distributions and experience evolutionary development in isolation are particularly prone to population decline as they have reduced capacity to respond to introduced predators and human activities (Arcilla et al. 2015). Okinawa is no exception, where there has been a documented spread of feral domestic animals and introduced predators throughout threatened species' habitats, and where at least $77 \mathrm{~km}^{2}$ of natural forest was lost to agricultural and urban development between the 1970s and early 2000s (Government of Japan 2014).

The greatest long-term threats to the Yanbaru Kuina population are deforestation, habitat fragmentation and forest thinning from development, agricultural expansion, and the construction of roads, dams and golf courses (BirdLife International 2017; Itō et al. 2000). Predation by feral cats, dogs and introduced species, particularly the Javan mongoose (Herpestes javanicus), has also had significant impact on the population (Yanbaru Wildlife Conservation Center 2015b; Ozaki et al. 2006). Predation is the primary cause of an observed northward contraction in the range of the Yanbaru Kuina, which contributed to an estimated $40 \%$ reduction in the species' total distribution from the late 1980s to 2004 (BirdLife International 2017;
NEW VOICES

IN JAPANESE STUDIES 
Ozaki et al. 2006; Arcilla et al. 2015). Other significant causes of mortality include vehicle collisions, particularly during the active breeding season, when Yanbaru Kuina dash across roads between forest patches, accounting for $70 \%$ of recorded deaths in one study conducted between 1998 and 2003 (Kotaka and Sawashi 2004). The Ministry of the Environment (MOE) has twice declared a 'state of emergency', in 2007 and 2010, in response to high levels of Yanbaru Kuina mortality on roads (Yamashina Institute for Ornithology 2011a). Recently, there has also been evidence of a genetic bottleneck in the Yanbaru Kuina population, whereby rapid population decline has changed the gene pool structure, effectively causing a decline in genetic diversity. This process has long-lasting impacts that cannot be readily reversed with an increase in population size (Ozaki et al. 2010).

\section{Conservation Action}

The Yanbaru Kuina is legally protected as a National Endangered Species and is recognised as a tennen kinenbutsu (天然記念物), or 'Natural Monument', by the Agency for Cultural Affairs (Collar et al. 2001b; Government of Japan Agency for Cultural Affairs 2017). ${ }^{4}$ A management plan for the protection and expansion of the Yanbaru Kuina population was outlined in 2004 and a captive breeding program was established in 2010 (Government of Japan MOE 2004, 2007; Yamashina Institute for Ornithology 2011a). The MOE has undertaken trapping and installed fencing in an attempt to reduce the mongoose population in the region with some success (Arcilla et al. 2015; Ozaki et al. 2006). Road alterations, such as concreted road edges that increase bird visibility, and fencing coupled with under-road wildlife tunnel crossings, have been installed in certain highway hotspots to reduce traffic collisions (Yamashina Institute for Ornithology 2007; The Ryukyu Shimpo 2012). A Yanbaru Kuina critical care centre was also established with the involvement of local veterinary surgeries in 2005, to respond to injured individuals and incubate rescued eggs (Yamashina Institute for Ornithology 2015, 2007). Habitat protection has until recently been limited to small tracts of Yanbaru forest, such as $0.23 \mathrm{~km}^{2}$ at Mount Yonaha (与那霸岳) (Collar et al. 2001b). Some NGOs have also secured habitat in the region, including the WBSJ, which manages the Yanbaru Okuma yachō hogoku (やんばる奥 間野鳥保護区; lit., 'Yanbaru Okuma Wild Bird Reserve') on a small parcel of land near Kunigami (国頭村; $0.031 \mathrm{~km}^{2}$ ) (WBSJ 2015). The recent designation of $136.22 \mathrm{~km}^{2}$ of the Yanbaru region as a national park, in September 2016, signals a significant step forward in habitat conservation for this species (Government of Japan MOE 2016; Yanbaru Wildlife Conservation Center 2010b).

When considering Yanbaru Kuina conservation, it is also important to take into account the US military presence in Okinawa. Although the US returned sovereignty of Okinawa to the Japanese government in 1972, it still maintains a number of large military bases in the region, including the Camp Gonsalves Jungle Warfare Training Center, which occupies approximately $25 \%$ of the 
Yanbaru region (Itō et al. 2000; IWGIA 2016). Access to forest areas in the Training Center is prohibited, and the area has been kept in a relatively natural state to create authentic conditions for jungle warfare training exercises (Itō et al. 2000). In December 2016, US forces formally announced the return of half of the Training Center land (approximately $40 \mathrm{~km}^{2}$ ) to the Japanese government (Mie 2016). However, this deal has been in exchange for a controversial development project to construct six US military helipads in forest areas near the Takae district (高江周辺) in Higashi, Yanbaru (Mie 2016). Clearing and construction for the 75-metre-wide helipads, which also require service roads, stalled after two helipads were completed in 2014, but then resumed in July 2016, much to the ire of local communities and NGOs who have maintained long-term sit-in protests near the site (No Helipad Takae Resident Society 2013; World Wildlife Fund Japan 2015; The Mainichi 2016). Citizen protests and resistance from politicians in the regional Okinawan administration against this and other projects-such as the new US air base planned for Henoko Bay, which will encroach on the habitat of the endangered dugong (Dugong dugon) - have been met with significant opposition from the Japanese government (IWGIA 2011; The Japan Times 2016). These development projects and land use by US military forces in Yanbaru highlight the complex socio-political context in which conservation efforts for the Yanbaru Kuina are occurring.

\section{Community Engagement with the Yanbaru Kuina}

Following its official discovery, the Yanbaru Kuina experienced considerable media attention and community interest (Collar et al. 2001b). However, as the Yanbaru Kuina was discovered only relatively recently, few historical community interactions have been documented, except for some sightings by local mountain workers of a bird they nicknamed agachi (アガチ; scatterbrain) or yamadui (ヤマドゥイ; mountain bird) (Yamashina Institute for Ornithology 2011a). As a flightless bird that inhabits dense forest, few people chance upon this species; even visiting ornithologists still had difficulty securing wild sightings after 1981 (Brazil 2013).

While the southern parts of Okinawa are home to urban centres, including the prefecture's largest city, Naha, the northern Yanbaru region is more sparsely populated with smaller settlements (Takahashi 2004). The villages of Kunigami, Higashi (東村) and Ōgimi (大宜味村), which neighbour Yanbaru Kuina habitat, have particularly embraced the appearance of this charismatic and endemic species (Yamashina Institute for Ornithology 2011a). These communities have a combined population of approximately 9,700 residents, and relative to the Okinawan average have a reduced share of young people under 15 years of age and more people over 65 (13\% and 31\% of the regional population, respectively) (Japan Bureau of Statistics 2015). It was in Kunigami that the MOE opened the Yanbaru Wildlife Conservation Center and Ufugi Nature Museum in 1999, its major contribution to conservation education and cultivation of community awareness for Yanbaru and its biodiversity (Yanbaru Wildlife Conservation Center 2010a). The Center features educational displays, facilities for lectures and activities, and resources for visitors. 
An active website is also maintained with information about the Yanbaru region, news of conservation activities and monitored threats, upcoming events, useful links and a nature blog (Yanbaru Wildlife Conservation Center 2015a).

Kunigami has adopted the Yanbaru Kuina as the symbol of their village, with the bird featuring on the village logo and on the sign farewelling visitors from the town, which says, "You're welcome again to Kunigami, the village of the Yanbaru Kuina” (またんめんそーれ ヤンバルクイナの里国頭村へ) (Zenkoku ijū navi 2015; Yamashina Institute for Ornithology 2011a). Since 2004, as declared by the Kunigami Assembly, 17 September has been celebrated as 'Yanbaru Kuina Day' (Yamashina Institute for Ornithology 2011a). Since 2007, the community 'Kuina Festival' has been held annually around this day in September, and includes guided walks, eco-activities, arts and crafts and an appearance by Kui-chan (クイちやん), the Yanbaru Wildlife Conservation Center mascot (Kunigami Village 2015a). Kui-chan is used as a drawcard at events like the Kuina Festival and during public awareness campaigns that support conservation activities for this species, riding on the wave of popular character mascots in Japan (Kunigami Village 2015a).

At the 2011 Kuina Festival, special events were held to celebrate 30 years since the species' official description, including lectures in Kunigami's Yanbaru kuina seitai tenji gakushū shisetsu（ヤンバルクイナ生態展示学習施設; lit., 'Yanbaru Kuina Ecology Exhibition and Learning Centre') (Yamashina Institute for Ornithology 2011b). This facility focuses specifically on the Yanbaru Kuina and features educational displays about their ecology and conservation activities, as well as providing the opportunity to see a live Yanbaru Kuina, which is housed at the Centre and has been officially named Kyon Kyon (キョンキョン) by the local school children (Kunigami Village 2015b; The Ryukyu Shimpo 2014). In Kunigami, visitors can also buy doughnuts (a local speciality) that feature the likeness of two Yanbaru Kuina sharing a doughnut on their packaging (Kunigami Village 2015c). At Cape Hedo to the north of Kunigami stands a larger-than-life, Yanbaru Kuinashaped lookout constructed to attract visitors (Yamashina Institute for Ornithology 2011a).

The strong history of engagement Okinawans have with environmental conservation issues is also an important consideration in this case study, particularly where development projects and US military operations have come into conflict with the natural heritage of the region (IWGIA 2015; Itō et al. 2000). In recent years, residents of Takae, a small northern district of Higashi, have been at the forefront of protest action against the US military, following the recommencement of helipad construction discussed earlier, in close proximity to this residential area of Higashi. Community members have maintained an organised, long-term campaign against the helipads, focusing on two major issues: firstly, the disruption from noise pollution and threat of accidents from Osprey helicopter training exercises; and secondly, the overarching concern for the region's surrounding forest and biodiversity (No Helipad Takae Resident Society 2013; The Mainichi 2016). Along with 
other wildlife, the Yanbaru Kuina has been utilised in campaign material by Takae community groups as a positive focus for action, with a cartoon likeness of the bird used to rally community support (No Helipad Takae Resident Society 2013). Amid the long-term turmoil over US military base operations and development in Okinawa, the Yanbaru Kuina appears to stand as a positive focus for environmental activities, a symbol of the unique natural assets in the region and a point of pride for the communities in Yanbaru.

It is important to note the distinction of naming this species the 'Yanbaru Kuina' or 'Yanbaru Rail' in Japan, instead of the 'Okinawa Rail', as designated in English. Yanbaru was little known outside of Okinawa before the discovery of this species, and this name was chosen in an effort to draw attention to the region's considerable biodiversity (Yamashina Institute for Ornithology 2015). In choosing the name 'Yanbaru Kuina', the scientists at the Yamashina Institute for Ornithology (who acquired and described the first type specimen of this species) also wanted to cultivate local community awareness and support, which they considered crucial for conservation (Yamashina and Mano 1981; Yamashina Institute for Ornithology 2011a, 2015). This is particularly important given many of the factors contributing to Yanbaru Kuina mortality have a direct human element, and so the success of conservation actions in addressing such threats relies on the cooperation of local people and effective public awareness campaigns (Yanbaru Wildlife Conservation Center 2015b).

A prime example of this is the issue of Yanbaru Kuina mortality from car collisions, which remains a significant threat to the species' small population, despite the installation of targeted warning signs and other road alterations (Yanbaru Wildlife Conservation Center 2016). This trend prompted the MOE to begin a public awareness campaign in 2014, producing posters and campaign material to highlight road-kill hotspots and encourage drivers to reduce speeds in Yanbaru (Naha Environment Office 2015). With increased interest in the region after the recent national park designation, campaigns will need to ensure driver awareness also extends to tourists. While the annual road-kill count fluctuates considerably and has yet to drop below the figure of 35 deaths recorded in 2010, when a state of emergency was last declared, figures do show that car fatalities have not increased in the two years since the introduction of the public awareness campaign (Yanbaru Wildlife Conservation Center 2016). These results not only highlight the value of this campaign for the Yanbaru Kuina but also the precarious nature of long-term conservation efforts, which can be derailed without continued community support.

Along with direct community cooperation, the case of the Yanbaru Kuina demonstrates the importance of negotiating cultural values and crosscultural differences in policy and law, which have implications for the implementation of conservation activities. Feral cats, a significant threat to this species and wildlife worldwide, are commonly subject to programs of lethal eradication as part of efforts to protect threatened and native wildlife species globally. In a review of Australian feral cat management by Doherty et al. 
(2017), there is little mention of negotiating community response to eradication by environmental authorities; rather, the focus is on improving the efficiency of management strategies to improve outcomes for native biodiversity.

Implementation of feral cat eradication programs in Okinawa, however, has proved to be complex for government authorities (Takahashi 2004). Despite the threat cats pose to the Yanbaru Kuina, there was considerable opposition from animal welfare groups and community members to euthanise feral cats caught in Okinawan forests (Takahashi 2004). The feral cat population has largely increased due to domestic cat abandonment, often in vulnerable habitats such as Yanbaru-a trend that may in turn be exacerbated by the region's ageing and shrinking population (Takahashi 2004; Japan Bureau of Statistics 2015). Cultural sensitivities and Buddhist traditions in Japan have in part fostered a reluctance to surrender pet cats to animal shelters for fear of euthanasia (Takahashi 2004; Kikuchi 2016). Cats also elicit a strong emotional response from the Japanese public, particularly as appreciation of kawaii (かわいい) or 'cute' things has become a cultural phenomenon (Nittono et al. 2012; The Japan Times 2015).

Feral cats also have a complicated legal status in Japan. They are not considered an 'alien species' under the Invasive Alien Species Act as they have been in Japan since before the Meiji Restoration-the arbitrary deadline designated for introduced species classification (Duffy and Capece 2012). Ambiguous definitions of 'domestic' versus 'feral' cats in the Wildlife Protection and Hunting Law, and the lack of provisions for feral cat management in the Animal Protection Law, create further difficulties for authorities, as legislation can be used by opposition groups to reinforce arguments against management strategies (Takahashi 2004). An alternative approach to neuter and release feral cats, which is growing in popularity elsewhere in Japan, was not possible in Yanbaru due to the considerable threat cats pose to native species (Takahashi 2004; Kikuchi 2016). Community resistance to euthanising feral cats was significant enough that a proportion of the captured animals were initially released, before a system to promote their adoption through animal shelters in Okinawa was introduced (Takahashi 2004). The legal framework and cultural sensitivities which have partly undermined the progress of feral cat management in Okinawa demonstrate the complexities of negotiating conservation action, even where a strategy is of significant conservation value to threatened species.

\section{ANALYSIS OF COMMUNITY ENGAGEMENT WITH CONSERVATION}

The inextricable link between the Yanbaru Kuina and the Yanbaru forests, and the evident charismatic appeal of this species for people in the region, have served to foster a strong community regard for the species, despite the relatively short timeframe it has been in the spotlight. The communities in Yanbaru celebrate the Yanbaru Kuina not only as a distinct member of Okinawa's regional biodiversity, but also as an important symbol of cultural identity, and as a drawcard for community events and tourism. The complex 
socio-cultural and political history of Okinawa, which has had a bearing on the engagement of people in Okinawa with their local biodiversity, may set this case apart from conservation examples in other parts of Japan. Divisive issues such as US military base operations and development projects, which have often been intertwined with environmental conservation issues, appear to have intensified attachment to the Yanbaru Kuina and other local species.

Considering that communities in Yanbaru and wider Okinawa are experiencing the effects of an ageing and shrinking population, as well as economic disadvantage relative to other parts of Japan, it is important to enhance the ability of local people to promote this species as a drawcard for tourists in a sustainable manner, so as to improve economic conditions in the region (Kakazu 2011; Japan Bureau of Statistics 2015). Since the return of Okinawan control to Japan, tourism has been an important and fastgrowing economic contributor in the region (Kakazu 2011). As natural features are an important element of Okinawa's appeal for visitors, this provides further motivation for communities to highlight the value of their local biodiversity, such as the Yanbaru Kuina. The snapshot of activities in this paper indicates that the local administration in Kunigami has endeavoured to cultivate a strong association with this species to create a community brand that draws attention to their town. The data in this paper is insufficient to indicate whether this has improved economic or job opportunities for people in this remote region of Okinawa, but the Yanbaru Kuina does appear to have contributed to social cohesion and community spirit in Kunigami, as a symbol that reinforces local identity.

The intangible cultural value and potential economic value recognised in the Yanbaru Kuina has manifested into investment by both government and community stakeholders to support facilities, events and campaigns associated with the Yanbaru Kuina and its conservation. While an analysis of the impact of these education and awareness initiatives on conservation outcomes for the Yanbaru Kuina is beyond the scope of this study, some preliminary observations can be made about the actions being undertaken. The value of education and community engagement as a means to encourage support for conservation programs has been widely established in the literature (Brewer 2002; Jacobson et al. 2006; Jiménez et al. 2014; Kobori 2009). Conservation education and community outreach initiatives can help people improve their knowledge and skills, promote environmentally conscious attitudes and behaviours, increase participation in active environmental issues, support conservation policies, and secure volunteers and funding (Jacobson et al. 2006; Jiménez et al. 2014). These initiatives need to "capture the imagination and interest of local people in a way that stimulates cooperation and conservation action" (Brewer 2002,4). However, the effectiveness of programs will differ depending on the type of engagement approach, the stakeholders involved, the socio-cultural context, and how well strategies are tailored to target audiences (Jacobson et al. 2006; Jiménez et al. 2014).

Brewer (2002) has identified outreach and partnership programs as two general approaches to conservation education, which are both valuable for 
engaging and educating the public. Outreach programs are characterised by primarily unidirectional communication of knowledge to an audience; for example, as lectures, workshops, educational exhibits and displays, and other public relations techniques (Brewer 2002; Jacobson et al. 2006).

Partnership programs place greater emphasis on incorporating contributions from different stakeholders where perspectives and information can be shared and synthesised between teachers and participants (Brewer 2002). Outreach programs, including wildlife education centres, lectures, wildlife viewing and public relations activities, have been common approaches in the case of the Yanbaru Kuina. In particular, the Yanbaru Wildlife Conservation Center and Kunigami's Yanbaru Kuina Ecology Exhibition and Learning Centre provide resources and spaces to learn about local biodiversity and coordinate public awareness appeals. These activities demonstrate a particular drive by Kunigami and the Japanese government to promote awareness of this species and Yanbaru.

Although the improvement of ecological and conservation literacy through information dissemination is a highly valuable exercise, some case studies suggest it may not be the most efficient means to change attitudes and behaviours (Jiménez et al. 2014; Lo et al. 2012). In a case study of social influences on conservation by Lo et al. (2012), it was found that "merely having a good understanding about a species' status is not likely to strengthen the intention to protect them" (910). This finding is consistent with other analyses of behaviour change, which demonstrate informational campaigns can be inefficient in effecting behaviour change if they only target people's intentions, which can be overwhelmed by habitual behaviours (Verplanken and Wood 2006). Human activities remain a considerable direct threat to the Yanbaru Kuina population. Therefore, protecting this species will rely on the efficacy of education and engagement programs to produce solutions that change individual behaviours to prevent accidental Yanbaru Kuina mortality.

Strategies may be most effective where elements of education, participation and communication can be combined, and can include partnerships with different stakeholders (Jiménez et al. 2014). In a summary and review of conservation education in Japan, Kobori (2009) commented that unique aspects of Japanese society placed Japan at an advantage in terms of the development and promotion of conservation outreach and education initiatives. These included the strong value ascribed to nature in Japanese cultural traditions, and a centralised government with significant technological capacity to collect and communicate information among government and non-government organisations and the public. A study by Healey et al. (2006) found that, in comparison to Canada, programs to promote participation in endangered species conservation in Japan "engage various levels of government and society in a more integrated way" (26). Indeed, hands-on and active approaches to conservation participation (for example, tree-planting and landscape regeneration projects) seem to be effective in Japan, especially where there is collaboration between 
different stakeholders, such as universities, local governments, NGOs and local community members (Kobori 2009; Primack et al. 2000), or where traditional activities are reinvigorated (Sakurai and Jacobson 2011; Kobori and Primack 2003).

Brewer (2002) has suggested that well-designed conservation education programs can "help participants enjoy and engage in science learning because they can recognize the effects and context of their learning" (6). It is clear that conservation engagement initiatives for the Yanbaru Kuina effectively integrate contributions from both government and non-government bodies and communities. However, it may be valuable to develop more programs that have greater emphasis on coordinated science-based learning, including hands-on activities where data can be collected and conservation goals can be monitored. In this way, programs can provide educational benefits to students and also improve the dialogue between communities and stakeholders involved in conservation activities, while also addressing conservation objectives for this species (Brewer 2002).

BirdLife International has recommended development of a "conservation education programme for Okinawa using this species [...] as [a] flagship species" (BirdLife International 2017). The use of individual wildlife species as appealing figureheads to draw attention to conservation of a larger ecosystem has proved to be successful in Japan (Kobori 2009). Social marketing techniques, including media campaigns, can be used as effective tools in conservation education to communicate ideas and suggest ways to change behaviours (Jacobson et al. 2006). As a distinctive and charismatic bird, the Yanbaru Kuina is a prime candidate to be a figurehead that increases attention to conservation of its own species, as well as for biodiversity in the greater Yanbaru region. Already, educational and community activities for the Yanbaru Kuina have enjoyed success, where social marketing techniques have tapped into the strong appeal of mascot characters in Japanese popular culture to engage diverse Japanese audiences.

In contrast, the use of Yanbaru Kuina mascots and imagery by organisations with interests outside of conservation can be problematic. Making use of the platform of community interest in the Yanbaru Kuina, various corporations and organisations have utilised the likeness of this species to highlight company engagement with the community. Given the challenging and complex relationship between the US military forces, the regional government and Okinawan citizens, it is no surprise that the Okinawa branch of the Japan Self-Defense Forces (SDF) has recognised the value of using the likeness of the Yanbaru Kuina as a public relations tool. The SDF has

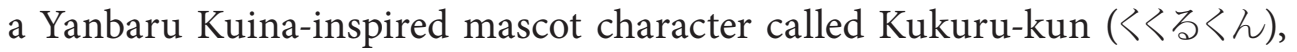
meaning 'heart' in the Okinawan language (Japan Self-Defense Forces Okinawa 2015). Kukuru-kun is said to have been rescued by the SDF after being hit by a car, and in gratitude Kukuru-kun now gives its time at community events as the SDF's 'public relations bird' (Japan Self-Defense Forces Okinawa 2015). In essence, all mascot characters are created to facilitate engagement with the public and personify an organisation's image, but in this case study the 
context is important. In contrast to the mascot of the Yanbaru Wildlife Conservation Center, Kui-chan, who is used in an educational context, the SDF mascot does not have the same potential to facilitate engagement with conservation awareness. In the same vein, the Coca-Cola Company in Japan, who has bottling operations in Okinawa, has modified some vending machines with equipment to record and collect Yanbaru Kuina vocalisations in partnership with the Okinawa Conservation \& Animal Welfare Trust (Ogata 2013; Okinawa Coca-Cola Bottling 2016). This commodification of the Yanbaru Kuina's perceived value and charismatic appeal to people in Okinawa has the potential to create a disconnect between the actual endangered species and the 'Kuina' characters these organisations have created, obscuring rather than contributing to conservation. In the long term, community engagement should emphasise the role of the Yanbaru Kuina as a member of the larger ecosystem of Yanbaru in order to also support the protection of species considered less valuable and appealing, and garner public support to encourage larger-scale action, including habitat conservation.

Many of the activities for the Yanbaru Kuina highlighted above target young people (Kunigami Village 2015a; Yanbaru Wildlife Conservation Center 2010a). Through the education centres, the Kuina Festival and the mascot characters, the Japanese government, NGOs and community members have used creative media to exploit the charismatic value of this species in order to communicate the importance of conservation to younger audiences. Wildlife visitor centres chiefly cater to a general audience, and especially young people, who are often considered "traditional environmental education stakeholders", and are thus an important group with whom to promote understanding and awareness of biodiversity and conservation (Jiménez et al. 2014, 837). However, as this species is at such risk, in the short term it may be more strategic to also target stakeholders who have a direct impact on the direction and implementation of conservation activities and environmental management, including university students and government bodies associated with key industries like farming, fisheries and forest management (Jiménez et al. 2014).

Socio-demographic characteristics may also influence how communities interact with species and whether they support management and conservation efforts (Kellert 1991; Sakurai et al. 2014). Japan has the highest proportion of people aged over 65 and a low proportion of people under 15 (26\% and 13\% of the total population, respectively), relative to global averages (The World Bank 2016a, b). This demographic pattern is also evident in Okinawa Prefecture and is more acute in less urban areas such as Yanbaru (Japan Bureau of Statistics 2015). Sakurai et al. (2014) found that perceptions and tolerance of wildlife in one Japanese province were influenced by the age of respondents and other socio-demographic variables, as well as by characteristics of the focus species. Older people were less tolerant of coexisting with problematic wildlife than younger generations, and species were seen more favourably when they were considered threatened, as opposed to native agricultural pests or introduced invasive species (Sakurai et al. 2014). Although this may have a minor influence on the 
Yanbaru Kuina as a native species, it highlights the importance of understanding variations in the perspectives and behaviour of different target audiences when designing conservation outreach and partnership programs in Japan.

Engagement and support for conservation can also be influenced by the social context and community standpoint on an issue, as opposed to a sense of personal responsibility (Lo et al. 2012). In these cases, development of group- and field-based activities as part of conservation education initiatives are valuable ways to foster "positive social influences" and "nurture a sense of collective achievement" (Lo et al. 2012, 900). Such programs have proved to be successful in other regions of Japan, and the strong community attachment to the Yanbaru Kuina would be valuable in this regard. Indeed, the species is already being used as a platform for social events, as discussed above, including the annual Kuina Festival (Kobori 2009). Communities in Yanbaru also have a strong foundation for environmental engagement, given the history of community action in response to the social and environmental implications of the US military presence and construction projects. However, the community opposition in Okinawa to feral cat euthanasia highlights that social and cultural dynamics can be a stumbling block for the implementation of important conservation measures (Takahashi 2004). Community consultation therefore remains very important when designing and implementing conservation activities in Japan.

On a larger scale, Japan faces the challenge of mainstreaming the value of biodiversity throughout society and government agencies, to enhance cooperation and ultimately improve its system of environmental management (Government of Japan 2014). Analyses of the Japanese biodiversity and wildlife conservation system agree there are still many aspects of legislation and management which need attention, including increasing resources, funding and bureaucratic power of environmental agencies, revitalising traditional rural management of wildlife and landscapes, improving management and monitoring of designated protected areas, enhancing policy and inter-institutional cooperation, and negotiating the strong forces of development (Knight 2010a, b; Takahashi 2009; OECD 2010). For example, the designation of part of the Yanbaru region as a national park in September 2016 represents significant progress towards protection of this region. However, the Japanese national park system has been criticised for emphasising the aesthetic and recreational value of parks, rather than their role in biodiversity conservation (Knight 2010a; Healey et al. 2006). It has become apparent in several cases that ostensibly protected areas remain vulnerable to development and human activities, and are not adequately resourced or staffed to respond efficiently to detrimental activities (Knight 2010a). Increased attention to Yanbaru as an ecotourism attraction, for example, will likely bring more visitors and traffic, and likely entail a disturbance of habitat (Tanaka et al. 2011). The continued monitoring of populations of threatened species like the Yanbaru Kuina in the national park needs to be paramount to ensure that the primary objective of the protected area is habitat and wildlife conservation. 


\section{CONCLUSION}

This case study demonstrates that the cultural value of wildlife, as recognised by communities found close to threatened species habitat, can drive interest in associated conservation efforts, even in a relatively short period of time. For the Yanbaru Kuina, community cooperation and consultation has necessarily been a key part of conservation efforts to target human activities that threaten this endangered population. This species has also provided impetus for government and local administration to invest in education facilities and community events in Yanbaru, which may increase momentum for largerscale conservation action. In simple terms, if communities in Yanbaru have found value in this species as an economic drawcard and symbol of regional identity that reinforces community spirit, they have something to lose if the Yanbaru Kuina disappears from their local biodiversity.

A key challenge in this case will be improving the capacity of existing conservation education facilities and campaigns to support science-based conservation efforts for the Yanbaru Kuina over the long term. With reference to successful characteristics of other conservation strategies in Japan and elsewhere, it could be advantageous to encourage partnerships and communication between different stakeholders, provide more opportunities for learning in social contexts, and further develop education programs that improve conservation literacy and incorporate scientific conservation objectives, such as monitoring or habitat restoration. The negative response to feral cat eradication has also shown the importance of community consultation.

Ultimately, the long-term success of Yanbaru Kuina conservation will rely on a variety of stakeholders to recognise the value of conserving biodiversity, and cooperate in challenging the strong socio-economic and political drivers that threaten this ecologically important region. This progress may be particularly complex in Okinawa with the apparent impasse in negotiations between the US military and Japanese government on one side, and local politicians and citizens on the other, to delay development projects in environmentally sensitive areas, highlighting that wildlife conservation rarely occurs in isolation from other contexts. This reinforces the value of investigating cross-cultural differences in approaches to environmental issues, in order to design biodiversity strategies that negotiate the biocultural context of conservation, and effectively encourage local people to engage and cooperate with conservation efforts for their local biodiversity.

\section{GLOSSARY}

CBD

MOE

NGO

SDF

WBSJ
Convention on Biological Diversity

Ministry of the Environment (Government of Japan)

non-governmental organisation

(Japan) Self-Defense Forces

Wild Bird Society of Japan 


\section{REFERENCES}

Akan International Crane Center (GRUS) [阿寒国際ツルセンター・グルス]. 2015. “Akan tanchō no sato Jinkō kyūji hasshō no ji" [阿寒丹頂の里人工給 餌発祥の地]. Accessed 3 August, 2015. http://aiccgrus.wixsite.com/aiccgrus.

Arcilla, N., C.-Y. Choi, K. Ozaki and C. A. Lepczyk. 2015. "Invasive Species and Pacific Island Bird Conservation: A Selective Review of Recent Research Featuring Case Studies of Swinhoe's Storm Petrel and the Okinawa and Guam Rail." Journal of Ornithology 156 (Suppl. 1): 199-207. http://doi.org/10.1007/s10336-015-1256-8.

Barua, M. and P. Jepson. 2010. "The Bull of the Bog: Bittern Conservation Practice in a Western Bio-cultural Setting." In Ethno-ornithology: Birds, Indigenous Peoples, Culture and Society, edited by S. Tidemann and A. Gosler, 301-12. London: Earthscan. http://doi.org/10.4324/9781849774758.

BirdLife International. 2015. "Species Factsheet: Red-crowned Crane Grus japonensis.” Accessed 3 August, 2015. http://datazone.birdlife.org/species/ factsheet/red-crowned-crane-grus-japonensis.

2016. "Hypotaenidia okinawae." The IUCN Red List of Threatened Species. Accessed 3 August, 2016. http://www.iucnredlist.org/details/summary/ $22692412 / 0$.

2017. "Species Factsheet: Okinawa Rail Hypotaenidia okinawae." Accessed 3 February, 2017. http://datazone.birdlife.org/species/factsheet/okinawarail-hypotaenidia-okinawae/text.

Brazil, M. 2013. “Tales From on the Trail of Okinawa's Rail," The Japan Times, 7 December. Accessed 10 August, 2015. http://www.japantimes.co.jp/ life/2013/12/07/environment/tales-from-on-the-trail-of-okinawas-rail.

Brewer, C. 2002. "Outreach and Partnership Programs for Conservation Education Where Endangered Species Conservation and Research Occur." Conservation Biology 16 (1): 4-6. http://doi.org/10.1046/j.1523-1739.2002. 01613.x.

Britton, D. and T. Hayashida. 1993. The Japanese Crane: Bird of Happiness. New York: Kodansha International.

Buizer, M., B. Elands and K. Vierikko. 2016. "Governing Cities ReflexivelyThe Biocultural Diversity Concept as an Alternative to Ecosystem Services." Environmental Science \& Policy 62: 7-13. http://doi.org/10.1016/j. envsci.2016.03.003.

Collar, N. J., A. Andreev, S. Chan, M. J. Crosby, S. Subramanya, and J. A. Tobias, eds. 2001a. "Red-crowned Crane." In Threatened Birds of Asia: The BirdLife International Red Data Book, 1226-53. Cambridge, UK: BirdLife International. 
.2001b. "Okinawa Rail." In Threatened Birds of Asia: The BirdLife International Red Data Book, 1260-64. Cambridge, UK: BirdLife International.

Daniel, T. C., A. Muhar, A. Arnberger, O. Aznar, J. W. Boyd, K. M. A. Chan, R. Costanza et al. 2012. "Contributions of Cultural Services to the Ecosystem Services Agenda." Proceedings of the National Academy of Sciences of the United States of America 109 (23): 8812-19. http://doi.org/10.1073/ pnas.1114773109.

De Groot, R. and P. S. Ramakrishnan. 2005. "Cultural and Amenity Services." In Ecosystems and Human Well-being-Current States and Trends: Findings of the Conditions and Trends Working Group, edited by R. Hassan, R. Scholes and N. Ash, 455-76. Washington: Island Press.

Doherty, T. S., C. R. Dickman, C. N. Johnson, S. M. Legge, E. G. Ritchie and J. C. Z. Woinarski. 2017. "Impacts and Management of Feral Cats Felis catus in Australia." Mammal Review 47 (2): 83-97.http://doi.org/10.1111/mam.12080.

Duffy, D. and P. Capece. 2012. "Biology and Impacts of Pacific Island Invasive Species. 7. The Domestic Cat (Felis catus).” Pacific Science 66 (2): 173-212. http://doi.org/10.2984/66.2.7.

Elands, B., K. Wiersum, A. Buijs and K. Vierikko. 2015. "Policy Interpretations and Manifestation of Biocultural Diversity in Urbanized Europe: Conservation of Lived Biodiversity." Biodiversity and Conservation 24 (13): 3347-66. http://doi.org/10.1007/s10531-015-0985-6.

Government of Japan. 2014. Fifth National Report of Japan to the Convention on Biological Diversity. Accessed 25 May, 2015. http://www.cbd.int/doc/world/ jp/jp-nr-05-en.pdf.

Government of Japan, Agency for Cultural Affairs [文化庁]. 2017. “Shiseki meishō tennen kinenbutsu: yanbaru kuina” [史跡名勝天然記念物: ヤンバルクイナ]. Accessed 10 May, 2017. http://kunishitei.bunka.go.jp/bsys/index_pc.html.

Government of Japan, Ministry of the Environment (MOE) [環境省]. 2004. “Yanbaru kuina hogo zōshoku jigyō keikaku” [ヤンバルクイナ保護増殖事 業計画]. Accessed 25 May, 2016. http://www.env.go.jp/nature/kisho/ hogozoushoku/pdf/jigyoukeikaku/yanbarukuina.pdf.

2007. "Yanbaru kuina no shiikuka hanshoku ni kansuru kihon hōshin no sakutei ni tsuite” [ヤンバルクイナの飼育下繁殖に関する基本方針の策定に ついて]. Accessed 12 May, 2015. http://www.env.go.jp/press/8518-print.html.

2012. The National Biodiversity Strategy of Japan 2012-2020. Accessed 25 May, 2015. http://www.cbd.int/doc/world/jp/jp-nbsap-v5-en.pdf.

2016. “Yanbaru kokuritsu kōen’ ga tanjō shimashita!” [ 「やんばる国立公 園」が誕生しました!]. Accessed 20 October, 2016. http://www.env.go.jp/ nature/np/yambaru.html. 
2017. “Kankyōshō zetsumetsukigushu kensaku kekka” [環境省絶滅危惧種検 索結果]. Accessed 18 May, 2017. http://ikilog.biodic.go.jp/rdb/env.

Hakkenberg, C. 2008. "Biodiversity and Sacred Sites: Vernacular Conservation Practices in Northwest Yunnan, China." Worldviews: Global Religions, Culture, and Ecology 12 (1): 74-90.http://doi.org/10.1163/156853508X276842.

Healey, M., M.-Y. Kuo and Y. Yamasaki. 2006. "Biodiversity and Endangered Species Conservation in Japan and Canada." Journal of Policy Studies [関西学院大学 総合政策学部研究会] 23: 21-28.

Higuchi, H. and R. B. Primack. 2009. "Conservation and Management of Biodiversity in Japan: An Introduction.” Biological Conservation 142 (9): 1881-83. http://doi.org/10.1016/j.biocon.2009.03.011.

International Crane Foundation. 2015. "Red-crowned Crane." Accessed 2 August, 2015. http://www.savingcranes.org/species-field-guide/red-crowned-crane.

International Union for Conservation of Nature (IUCN). 2016. Introduction. Accessed 15 December, 2016. http://www.iucnredlist.org/about/introduction.

International Work Group for Indigenous Affairs (IWGIA). 2011. “Japan.” In The Indigenous World 2011, edited by C. Erni and C. Nilsson, 236-43. Copenhagen: IWGIA. PDF e-book. http://www.iwgia.org/publications/ search-pubs?publication_id=454.

. 2015. "Japan." In The Indigenous World 2015, edited by C. Erni and C. Nilsson, 234-40. Copenhagen: IWGIA. PDF e-book. http://www.iwgia. org/publications/search-pubs?publication_id=716.

.2016. "Japan." In The Indigenous World 2016, edited by C. Erni, S. Leth and S. Stidsen, 232-38. Copenhagen: IWGIA. PDF e-book. http://www. iwgia.org/publications/search-pubs?publication_id=740.

Itō, Y., K. Miyagi and H. Ota. 2000. "Imminent Extinction Crisis among the Endemic Species of the Forests of Yanbaru, Okinawa, Japan." Oryx 34 (4): 305-16. http://doi.org/10.1046/j.1365-3008.2000.00136.x.

Jacobson, S. K., M. D. McDuff and M. C. Monroe. 2006. Conservation Education and Outreach Techniques. Oxford: Oxford University Press.

http://doi.org/10.1093/acprof:oso/9780198567714.001.0001.

. 2006. "Chapter 9: Marketing Conservation." In Conservation Education and Outreach Techniques, 263-96 Oxford: Oxford University Press. http:// doi.org/10.1093/acprof:oso/9780198567714.003.0010.

Japan Bureau of Statistics. 2015. Okinawa-ken dai 6 hyō nenrei (3 kubun), danjo betsu jinkō oyobi nenrei betsu wariai-todōfuken, shikuchōson (shōwa 55 nen-heisei 27 nen) [沖縄県 第6表 年齢 (3区分)、男女別人口及び年齢別 割合 都道府県、市区町村 (昭和55年～平成27年) ]. Accessed 2 January, 2017. http://www.e-stat.go.jp/SG1/estat/GL08020103.do?_toGL08020103_\&tclass ID $=000001007702 \&$ cycleCode $=0 \&$ requestSender $=$ search . 
2016. Japan Statistical Yearbook 2016. Accessed 26 October, 2016. http://www.stat.go.jp/english/data/nenkan/65nenkan/index.htm.

Japan Self-Defense Forces Okinawa [沖縄 自衛隊]. 2015. “Okinawa chihon no

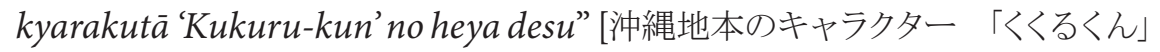
の部屋です]. Accessed 21 August, 2015. http://www.mod.go.jp/pco/okinawa/ okinawa1/kukuru/kukuru.html.

The Japan Times. 2015. "Railway in Japan with Cat for a Stationmaster to Get Continued Public Support," 17 November. Accessed 4 February, 2017. http:// www.japantimes.co.jp/news/2015/11/17/national/railway-japan-catstationmaster-get-continued-public-support.

. 2016. "Okinawa Gets Largest Chunk of Land Back from U.S. Military since '72," 22 December. Accessed 4 February, 2017. http://www.japantimes. co.jp/news/2016/12/22/national/okinawa-gets-largest-chunk-land-back-u-smilitary-since-72.

Japanese Red Data Search System [日本のレッドデータ検索システム]. 2016a. “Okinawa-ken” [沖縄県]. Accessed 20 October, 2016. http://jpnrdb.com/ search.php?mode=region\&q=47\&pageID=1.

2016b. “Yanbaru kuina” [ヤンバルクイナ]. Accessed 15 October, 2016.

http://jpnrdb.com/search.php?mode=map\&q=02090030147.

Jepson, P. 2010. “Towards an Indonesian Bird Conservation Ethos: Reflections From a Study of Bird-keeping in the Cities of Java and Bali." In Ethno-ornithology: Birds, Indigenous Peoples, Culture and Society, edited by S. Tidemann and A. Gosler, 313-30. London: Earthscan.

Jiménez, A., I. Iniesta-Arandia, M. Muñoz-Santos, B. Martín-López, S. K. Jacobson, and J. Benayas. 2014. "Typology of Public Outreach for Biodiversity Conservation Projects in Spain." Conservation Biology 28 (3): 829-40. http://doi.org/10.1111/cobi.12220.

Kakazu, H. 2011. "Sustainable Island Tourism: The Case of Okinawa." In Island Tourism: Sustainable Perspectives, edited by J. Carlsen and R. Butler, 171-85. Wallingford, UK: CAB International.

Katoh, K., S. Sakai and T. Takahashi. 2009. "Factors Maintaining Species Diversity in Satoyama, a Traditional Agricultural Landscape of Japan." Biological Conservation 142 (9): 1930-36. http://doi.org/10.1016/j.biocon. 2009.02.030.

Katsue, F. and M. Yukihiro. 2011. "Satoyama Management in the Twenty-first Century: The Challenge of Sustainable Use and Continued Biocultural Diversity in Rural Cultural Landscapes." Landscape and Ecological Engineering 7 (2): 161-62. http://doi.org/10.1007/s11355-011-0163-2.

Kawauchi, S. and R. F. McCarthy. 1998. "The Gratitude of the Crane." In Once Upon a Time in Ghostly Japan, edited by S. Kawauchi and R. F. McCarthy, 11-25. Tokyo: Kodansha International. 
Kellert, S. R. 1991. “Japanese Perceptions of Wildlife." Conservation Biology 5 (3): 297-308. http://doi.org/10.1111/j.1523-1739.1991.tb00141.x.

Kikuchi, D. 2016. “Campaign Targets Japan's Stray Cat Problem," The Japan Times, 23 November. Accessed 5 February, 2017. http://www.japantimes.co.jp/ news/2016/11/23/national/social-issues/campaign-targets-japans-stray-catproblem.

Kirchman, J. J. 2012. "Speciation of Flightless Rails on Islands: A DNA-Based Phylogeny of the Typical Rails of the Pacific." The Auk 129 (1): 56-69. http://doi.org/10.1525/auk.2011.11096.

Knight, C. 2010a. "Natural Environments, Wildlife, and Conservation in Japan." The Asia-Pacific Journal: Japan Focus 8 (4). Accessed 18 May, 2017. http://www.japanfocus.org/-Catherine-Knight/3292/article.html.

.2010b. "The Nature Conservation Movement in Post-War Japan." Environment and History 16 (3): 349-70. http://doi.org/10.3197/096734010X 519799.

Knight, J. 2006. Waiting for Wolves in Japan: An Anthropological Study of Peoplewildlife Relations. Honolulu: University of Hawai'i Press.

Kobori, H. 2009. "Current Trends in Conservation Education in Japan." Biological Conservation 142 (9): 1950-57. http://doi.org/10.1016/j.biocon.2009.04.017.

Kobori, H. and R. B. Primack. 2003. "Participatory Conservation Approaches for Satoyama, the Traditional Forest and Agricultural Landscape of Japan." AMBIO: A Journal of the Human Environment 32 (4): 307-11. http://doi.org/10.1579/0044-7447-32.4.307.

Kotaka, N. and Y. Sawashi. 2004. "The Road-kill of the Okinawa Rail Gallirallus okinawae." Journal of the Yamashina Institute for Ornithology 35 (2): 134-43. http://doi.org/10.3312/jyio.35.134.

Kunigami Village [国頭村]. 2015a. “'Dai 9 kai Aha damu, kuina matsuri” kaisai ni suite”[『第9回 安波ダム・クイナまつり』開催について], 2 September. Accessed 21 August, 2015. http://kunigami-kikakukanko.com/news2/?p=658.

2015b. “Yanbaru kuina seitai tenji gakushū shisetsu” [ヤンバルクイナ生態展 示学習施設]. Accessed 21 August, 2015. http://kunigami-kikakukanko. com/itiran/yanbarukuina.html.

2015c. “Kunigami-son ni tsuite” [国頭村について]. Accessed 21 August, 2015. http://kunigami-kikakukanko.com/about/index.html.

Kuroda, N. 1993. "Morpho-anatomy of the Okinawa Rail Rallus okinawae." Journal of the Yamashina Institute for Ornithology 25 (1): 12-27. http://doi. org/10.3312/jyio1952.25.12.

Lo, A.Y., A. T. Chow and S. M. Cheung. 2012. "Significance of Perceived Social Expectation and Implications to Conservation Education: Turtle Conservation as a Case Study." Environmental Management 50 (5): 900-13. http://doi.org/10.1007/s00267-012-9926-2. 
Maffi, L. 2010a. "Biocultural Diversity and the Future of Sustainability." In Biocultural Diversity Conservation: A Global Sourcebook, edited by L. Maffi and E. Woodley, 191-96. London: Earthscan.

.2010b. "What is Biocultural Diversity?" In Biocultural Diversity Conservation: A Global Sourcebook, edited by L. Maffi and E. Woodley, 3-11. London: Earthscan.

. 2010c. "Why is a Biocultural Approach Relevant for Sustaining Life in Nature and Culture?" In Biocultural Diversity Conservation: A Global Sourcebook, edited by L Maffi and E Woodley, 13-20. London: Earthscan.

The Mainichi. 2016. "Protesters, Riot Police Clash in Okinawa as Helipad Construction Resumes," 22 July. Accessed 15 October, 2016. http://mainichi. jp/english/articles/20160722/p2a/00m/0na/013000c.

Matthiessen, P. 1995. "The Cranes of Hokkaido." Audubon, July-August. http:// www.audubon.org/magazine/from-archives-cranes-hokkaido-petermatthiessen.

Mie, A. 2016. "U.S. Return of Okinawa Training Area Faces Harsh Criticism from Local Residents," The Japan Times, 21 December. Accessed 15 January, 2017. http://www.japantimes.co.jp/news/2016/12/21/national/u-s-returnokinawa-training-area-faces-harsh-criticism-local-residents.

Millennium Ecosystem Assessment. 2005. Ecosystems and Human Well-being: Biodiversity Synthesis. Washington, DC: World Resources Institute.

Naha Environment Office [那覇自然環境事務所]. 2015. “Yanbaru kuina ni yasashī kokorodzukai o onegaishimasu”[ヤンバルクイナにやさしい心づかいをお願いし ます]. Accessed 8 August, 2015. http://kyushu.env.go.jp/naha/wildlife/ mat/m_1_4.html.

Nittono, H., M. Fukushima, A. Yano and H. Moriya. 2012. "The Power of Kawaii: Viewing Cute Images Promotes a Careful Behavior and Narrows Attentional Focus.” PLoS ONE 7 (9): e46362. http://doi.org/10.1371/journal.pone.0046 362.

No Helipad Takae Resident Society. 2013. "Voice of Takae (1 October 2013)." Accessed 5 December, 2016. http://nohelipadtakae.org/fi ks/VOT-english2013Oct.pdf.

Ogata, K. 2013. "Gone to the Birds: Vending Machines Designed to Save the Okinawan Rail," Coca-Cola Company, 30 July. Accessed 20 August, 2015. http://www.coca-colacompany.com/innovation/gone-to-thebirds-vending-machines-designed-to-save-the-okinawan-rail.

Okinawa Coca-Cola Bottling [沖縄コカ・コーラボトリング会社]. 2016. “Mizu o mamoru tame ni koka kōra ga dekiru itsutsu no koto” [水を守るためにコカ・コーラ ができる5つのこと]. Accessed 15 October, 2016. http://www.okinawa.ccbc. co.jp/environment.

Organisation for Economic Co-operation and Development (OECD). 2010. OECD Environmental Performance Reviews: Japan 2010. Paris: OECD Publishing. 
Ozaki, K., S. Komeda, T. Baba, Y. Toguchi and T. Harato. 2006. "Declining Distribution of the Okinawa Rail: Impact of Introduced Predators." Journal of Ornithology 147 (Suppl. 1): 103-104. http://doi.org/10.1007/s10336006-0093-1.

Ozaki, K., Y. Yamamoto and S. Yamagishi. 2010. "Genetic Diversity and Phylogeny of the Endangered Okinawa Rail, Gallirallus okinawae." Genes \& Genetic Systems 85 (1): 55-63. http://doi.org/10.1266/ggs.85.55.

Primack, R., H. Kobori and S. Mori. 2000. "Dragonfly Pond Restoration Promotes Conservation Awareness in Japan." Conservation Biology 14 (5): 1553-54. http://doi.org/10.1046/j.1523-1739.2000.99549.x.

Pungetti, G., G. Oviedo and D. Hooke. 2012. "Introduction." In Sacred Species and Sites: Advances in Biocultural Conservation, edited by G. Pungetti, G. Oviedo and D. Hooke, 1-10. Cambridge: Cambridge University Press.

Rands, M. R. W., W. M. Adams, L. Bennun, S. H. M. Butchart, A. Clements, D. Coomes, A. Entwistle et al. 2010. "Biodiversity Conservation: Challenges Beyond 2010." Science 329 (5997): 1298-303. http://doi.org/10.1126/ science.1189138.

The Ryukyu Shimpo [琉球新報]. 2012. “Kuina sukue, minna no chikara de Sen'yō dōro 74 wa tsūka” [クイナ救え、みんなの力で 専用道路73羽通過], 21 September. Accessed 15 December, 2016. http://ryukyushimpo.jp/ news/prentry-197132.html.

.2014. “Kyon kyon yoroshiku ne Yanbaru kuina namae kettei”[キョンキョンよ ろしく㸚 ヤンバルクイナ名前決定], 16 February. Accessed 15 December, 2016. http://ryukyushimpo.jp/news/prentry-219555.html.

Sakurai, R. and S. K. Jacobson. 2011. "Evaluation of the Monkey-Persimmon Environmental Education Program for Reducing Human-Wildlife Conflicts in Nagano, Japan." Applied Environmental Education \& Communication 10: 43-51. http://doi.org/10.1080/1533015X.2011.549798.

Sakurai, R., S. K. Jacobson and G. Ueda. 2014. "Public Perceptions of Significant Wildlife in Hyogo, Japan." Human Dimensions of Wildlife 19 (1): 88-95. http://doi.org/10.1080/10871209.2014.842026.

Sasaki, K., Y. Sasaki and S. F. Fox. 2010. "Endangered Traditional Beliefs in Japan: Influences on Snake Conservation." Herpetological Conservation and Biology 5 (3): 474-85. http://www.herpconbio.org/Volume_5/Issue_3/Sasaki_ etal_2010.pdf.

Sbeghen, M. 2015. "Cultural Engagement with Three Threatened Bird Species in Japan: Community Interactions with Wildlife Conservation.” Unpublished Honours thesis, University of Queensland.

Takahashi, M. A. 2004. "Cats v. Birds in Japan: How to Reconcile Wildlife Conservation and Animal Protection." Georgetown International Environmental Law Review 17 (1): 135-59. 
2009. "Overview of the Structure and the Challenges of Japanese Wildlife Law and Policy." Biological Conservation 142 (9): 1958-64. http://doi. org/10.1016/j.biocon.2009.05.009.

Tanaka, S., A. Kaku, and M. Nezu. 2011. "Current Status and Issues Surrounding Ecotourism in the Shiretoko Region (World Natural Heritage Site)." Journal of Agricultural Science, Tokyo University of Agriculture 56 (1): 25-35.

United Nations Environment Programme. 2010. "Welcome to COP10." Accessed 15 July, 2015. http://www.cbd.int/cop10.

.2014a. "Convention on Biological Diversity: Japan Country Profile." Accessed 5 October, 2014. http://www.cbd.int/countries/profile/default. shtml? country=jp\#measures.

2014b. "History of the Convention." Accessed 5 October, 2014. http://www. cbd.int/history/default.shtml.

2014c. "Aichi Biodiversity Targets." Accessed 5 October, 2014. http://www. cbd.int/sp/targets/default.shtml.

Verplanken, B. and W. Wood. 2006. "Interventions to Break and Create Consumer Habits.” Journal of Public Policy \& Marketing 25 (1): 90-103.

Verschuuren, B. 2012. "Integrating Biocultural Values in Nature Conservation: Perceptions of Culturally Significant Sites and Species in Adaptive Management." In Sacred Species and Sites: Advances in Biocultural Conservation, edited by G. Pungetti, G. Oviedo and D. Hooke, 231-46. Cambridge: Cambridge University Press.

Von Treuenfels, C. 2006. The Magic of Cranes. New York: Abrams.

Wild Bird Society of Japan (WBSJ) [日本野鳥の会]. 2007. “Tsurui-Itō tanchō sankuchuari Shisetsu gaiyō, riyō annai” [鶴居・伊藤タンチョウサンクチュ アリ施設概要・利用案内]. Accessed 14 August, 2015. http://park15.wakwak. com/ tancho/sanc_info.html.

.2014. “Nihon yachōnokai Enkaku” [日本野鳥の会 沿革]. Accessed 10 August, 2014. http://www.wbsj.org/about-us/summary/history.

. 2015. “Yanbaru Okuma yachō hogoku” [やんばる奥間野鳥保護区]. Accessed 15 August, 2015. http://www.wbsj.org/activity/conservation/bird-reserve/ yanbaru_okuma.

The World Bank. 2015. "Percentage of Population in Rural Areas (in \% of Total Population).” Accessed 24 August, 2015. http://data.worldbank.org/ indicator/SP.RUR.TOTL.ZS/countries.

2016a. "Population Ages 65 and Above (\% of Total)." Accessed 20 October, 2016. http://data.worldbank.org/indicator/SP.POP.65UP.TO.ZS?year_high_ desc $=$ true. 
2016b. "Population Ages 0-14 (\% of Total)." Accessed 20 October, 2016. http://data.worldbank.org/indicator/SP.POP.0014.TO.ZS?year_high_ desc $=$ false.

World Wildlife Fund Japan. 2015. No Military Helipads in Yanbaru Forest. Accessed 20 August, 2015. http://www.wwf.or.jp/activities/lib/pdf/yanbaru0706e.pdf.

Yamashina Institute for Ornithology [山階鳥類研究所]. 2007. “Yanbaru hogo no saizensen Okinawa yanbaru o aruku” [やんばる保護の最前線沖縄やんば るを歩く]. Accessed 20 August, 2015. http://www.yamashina.or.jp/hp/ yomimono/yambarukuina/06yambaru.html.

2011a. Yanbaru kuina no rekishi [ヤンバルクイナの歴史]. Accessed 20 August, 2015. http://www.yamashina.or.jp/hp/yomimono/yambarukuina/04genzai. html.

. 2011b. "Yanbaru kuina hakken 30 shūnen no ibento ga kaisai saremashita" [ヤンバルクイナ発見30周年のイベントが開催されました]. Accessed 20 August, 2015. http://www.yamashina.or.jp/hp/wadai/backnumber/2011_11_1.html.

. 2015. “Yanbaru kuinatte donna tori?” [ヤンバルクイナってどんな鳥?]. Accessed 20 August, 2015. http://www.yamashina.or.jp/hp/yomimono/ yambarukuina/01donnatori.html.

Yamashina, Y. and T. Mano. 1981. "A New Species of Rail from Okinawa Island." Journal of the Yamashina Institute for Ornithology 13 (3): 147-52_3. http:// doi.org/10.3312/jyio1952.13.147.

Yanbaru Wildlife Conservation Center [やんばる野生生物保護センター]. 2010a. “Sentā ni tsuite” [センターについて]. Accessed 21 August, 2015. http://www. ufugi-yambaru.com/annai/index.html.

2010b. “Kokuritsu kōenka ni muketa kentō ni tsuite" [国立公園化に向けた検 討について]. Accessed 21 August, 2015. http://www.ufugi-yambaru.com/ torikumi/kouen.html.

.2015a. Yanbaru Wildlife Conservation Center, website. Accessed 21 August, 2015. http://www.ufugi-yambaru.com/index.html.

. 2015b. “Yanbaru kuina” [ヤンバルクイナ]. Accessed 21 August, 2015. http:// www.ufugi-yambaru.com/torikumi/kishyou_kuina.html.

. 2016. Heisei 28 nen no yanbaru chiiki ni okeru yasei dōbutsu no kōtsū jiko kakunin jōkyō [平成28年のやんばる地域における野生動物の交通事故 確認状況]. Accessed 4 February, 2017. http://www.ufugi-yambaru.com/ torikumi/documents/2016.pdf.

Zenkoku ijū nabi [全国移住ナビ]. 2015. “Kunigami-son” [国頭村]. Accessed 15 August, 2015. http://www.iju-navi.soumu.go.jp/onl/okinawa/kunigami/ ?cd_jichitai=47301. 